\title{
Biomass burning aerosol emissions from vegetation fires: particle number and mass emission factors and size distributions
}

\author{
S. Janhäll, M. O. Andreae, and U. Pöschl \\ Biogeochemistry Department, Max Planck Institute for Chemistry, P.O. Box 3060, 55020 Mainz, Germany
}

Received: 6 July 2009 - Published in Atmos. Chem. Phys. Discuss.: 14 August 2009

Revised: 28 December 2009 - Accepted: 10 January 2010 - Published: 9 February 2010

\begin{abstract}
Aerosol emissions from vegetation fires have a large impact on air quality and climate. In this study, we use published experimental data and different fitting procedures to derive dynamic particle number and mass emission factors $\left(\mathrm{EF}_{\mathrm{PN}}, \mathrm{EF}_{\mathrm{PM}}\right)$ related to the fuel type, burning conditions and the mass of dry fuel burned, as well as characteristic $\mathrm{CO}$-referenced emission ratios (PN/CO, PM/CO). Moreover, we explore and characterize the variability of the particle size distribution of fresh smoke, which is typically dominated by a lognormal accumulation mode with count median diameter around $120 \mathrm{~nm}$ (depending on age, fuel and combustion efficiency), and its effect on the relationship between particle number and mass emission factors.

For the particle number emission factor of vegetation fires, we found no dependence on fuel type and obtained the following parameterization as a function of modified combustion efficiency (MCE): $\mathrm{EF}_{\mathrm{PN}}=34 \times 10^{15} \times(1-\mathrm{MCE}) \mathrm{kg}^{-1} \pm$ $10^{15} \mathrm{~kg}^{-1}$ with regard to dry fuel mass (d.m.). For the fine particle mass emission factors $\left(\mathrm{EF}_{\mathrm{PM}}\right)$ we obtained $(86-$ $85 \times \mathrm{MCE}) \mathrm{g} \mathrm{kg}^{-1} \pm 3 \mathrm{~g} \mathrm{~kg}^{-1}$ as an average for all investigated fires; $(93-90 \times \mathrm{MCE}) \mathrm{g} \mathrm{kg}^{-1} \pm 4 \mathrm{~g} \mathrm{~kg}^{-1}$ for forest; $\left(67-65 \times\right.$ MCE) $\mathrm{g} \mathrm{kg}^{-1} \pm 2 \mathrm{~g} \mathrm{~kg}^{-1}$ for savanna; $(63-62 \times$ MCE) $\mathrm{g} \mathrm{kg}^{-1} \pm 1 \mathrm{~g} \mathrm{~kg}^{-1}$ for grass.

For the $\mathrm{PN} / \mathrm{CO}$ emission ratio we obtained an average of $(34 \pm 16) \mathrm{cm}^{-3} \mathrm{ppb}^{-1}$ exhibiting no systematic dependence on fuel type or combustion efficiency. The average PM/CO emission ratios were $(0.09 \pm 0.04) \mathrm{g} \mathrm{g}^{-1}$ for all investigated fires; $(0.13 \pm 0.05) \mathrm{g} \mathrm{g}^{-1}$ for forest; $(0.08 \pm 0.03) \mathrm{g} \mathrm{g}^{-1}$ for savanna; and $(0.07 \pm 0.03) \mathrm{g} \mathrm{g}^{-1}$ for grass.

The results are consistent with each other, given that particles from forest fires are on average larger than those from savanna and grass fires. This assumption and the above parameterizations represent the current state of knowledge, but
\end{abstract}

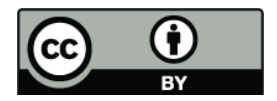

Correspondence to: S. Janhäll (s.janhall@mpic.de) they are based on a rather limited amount of experimental data which should be complemented by further measurements. Nevertheless, the presented parameterizations appear sufficiently robust for exploring the influence of vegetation fires on aerosol particle number and mass concentrations in regional and global model studies.

\section{Introduction}

Aerosol particle emissions from vegetation fires have large impacts on both climate and air quality (Yokelson et al., 2007; Andreae and Crutzen, 1997; Andreae et al., 2004). During burning periods, the visibility in affected areas can be heavily reduced, and the health effects on the local populations can be substantial. Biomass burning particles are efficient cloud condensation nuclei ( $\mathrm{CCN})$ and can influence the formation of clouds and precipitation (Luderer et al., 2006; Trentmann et al., 2006, Kivekäs, 2008; Reid et al., 2005; Reutter et al., 2009; Roberts et al., 2002; Rissler et al., 2004; Feingold et al., 2001; Asa-Awuku et al., 2008; Rose et al., 2008; Rosenfeld et al., 2008).

There is a growing interest in the indirect aerosol effect in climate models, but to fully represent the effect of aerosol emissions on cloud properties, improved particle number emission factors are needed (Andreae and Rosenfeld, 2008; Fuzzi et al., 2006; Lohmann et al., 2007). Currently, emission factors are mainly related to fuel types, but as the understanding of the fire process increases, the emission factors are not just treated as pure averages over the fire but can be related to fire properties as well (Hu et al., 2008; van der Werf et al., 2006; Schultz et al., 2008; Thonicke and Cramer, 2006; Hodzic et al., 2007). In this way, changes in the fire process due to, e.g., meteorological effects can also be taken into account in the models.

Particle emissions from biomass burning are dominated by an accumulation mode, with a count median diameter

Published by Copernicus Publications on behalf of the European Geosciences Union. 
of $100-150 \mathrm{~nm}$, together with two smaller modes; a coarse mode, and occasionally also a nucleation mode (Reid et al., 2005). The composition of the particles depends both on the fuel and on the burning process. The coarse mode particles consist of dust, carbon aggregates, ash and unburned parts of the fuel (Hungershoefer et al., 2008; Formenti et al., 2003; Gaudichet et al., 1995), while the accumulation mode consists mostly of organic matter, with soot carbon and inorganic species making up $\sim 10 \%$ each (Reid et al., 2005). Of the organic matter $40-80 \%$ is water soluble and $20-40 \%$ consists of acids (Reid et al., 2005), while alcohols and sugars, e.g., levoglucosan, make up less than $5 \%$ of the organic matter (Oros et al., 2006).

In the size range between the coarse and the accumulation modes, at a particle diameter around $1 \mu \mathrm{m}$, the emissions of both particle number and particle mass are minor (Radke et al., 1991; Falkovich et al., 2005; Hardy et al., 1996; Hays et al., 2005). This study focuses on the accumulation mode with a count median diameter around $120 \mathrm{~nm}$ and a mass median diameter around $240 \mathrm{~nm}$, which includes most of the particles, both by number and mass (Reid et al., 2005).

The particle size distribution of biomass burning emissions is extremely dynamic in the initial plume. Close to the fire, i.e., less than a few minutes away, a nucleation mode is often present. It is mainly detected in laboratory studies (Hays et al., 2005; Wardoyo et al., 2006; Keshtkar and Ashbaugh, 2007), but also in the field (Formenti et al., 2003; Sinha et al., 2003). These particles can be numerous, but have almost no mass and little influence on aerosol optical properties and $\mathrm{CCN}$ activity. Normally at a timescale of minutes up to half an hour, the nucleation mode particles transfer into the accumulation mode.

Compared to the accumulation mode, the coarse particles are few, but can make up a significant fraction of the particle mass. Most of the data show a limited amount of coarse particles in the biomass plume (Reid et al., 2005; Schafer et al., 2008), e.g., a ratio of $\mathrm{PM}_{10}$ to $\mathrm{PM}_{2.5}$ of $1.3 \pm 0.2$ for vegetation fire plumes compared to $2.4 \pm 0.5$ for background conditions in Montana (Ward et al., 2006). Radke et al. (1991) found that, on average, the coarse mode accounts for about $20 \%$ of the mass of smoke aerosol emitted. Particles in smoke plumes can reach quite large sizes: Instrumental observations show continuous log-normal size distributions reaching the millimeter size range (Radke et al., 1990, D. Rosenfeld, unpublished data, 2002), and visual observations of the fallout below fire plumes frequently show centimeter- to meter-sized objects (ash, char, burning branches, etc.).

The aim of this study is to parameterize the emission of biomass burning particles from vegetation fires. We have compiled all available literature data, present particle number and mass emission factors and ratios, and relate these to combustion efficiency and fuel type. We have analyzed three fuel types; forest, savanna and grass. Particle number and particle mass emissions are described separately and related through particle size distributions. This gives a consistency check on the results obtained, and also provides a starting point for the continuation of emission studies, both theoretical and experimental.

\section{Definitions and methods}

The emission factor (EF) is defined as the amount of aerosol particles that are emitted per kg of dry fuel mass burned; and is measured either as particle mass $\left(\mathrm{EF}_{\mathrm{PM}}\right)$ or as particle number $\left(\mathrm{EF}_{\mathrm{PN}}\right)$. To estimate the amount of fuel in an open vegetation fire, where weighing of the fuel is not possible for practical reasons, the common approach is to measure the various carbon species in the smoke. The assumption is made that all carbon in the burned part of the fuel is found in the smoke, and generally that the carbon content of the fuel is $45 \%$ of the mass (Andreae and Merlet, 2001). The other approach used is to scale the particle emissions to carbon monoxide, and to present $\mathrm{CO}$-referenced emission ratios (PN/CO, PM/CO). PN/CO usually refers to the particle number concentration at $100 \mathrm{kPa}$ and $298 \mathrm{~K}$ divided by the $\mathrm{CO}$ concentration or volume mixing ratio, respectively (common unit: $\mathrm{cm}^{-3} \mathrm{ppb}^{-1}$ ), while PM/CO is the ratio of particle and $\mathrm{CO}$ mass concentrations (common unit: $\mathrm{g} \mathrm{g}^{-1}$ ).

The combustion efficiency (CE) of a fire is generally defined as the amount of carbon released in the form of carbon dioxide divided by the total amount of carbon released. In many cases only $\mathrm{CO}$ and $\mathrm{CO}_{2}$ are measured, and the modified combustion efficiency (MCE) is used to characterize burning conditions. The MCE is defined as the amount of carbon released as $\mathrm{CO}_{2}$ divided by the amount of carbon released as $\mathrm{CO}_{2}$ plus $\mathrm{CO}$ (Yokelson et al., 1996, Eq. 1). The difference between MCE and CE is normally less than a few percent (e.g., Guyon et al., 2005), and for this study MCE will be used exclusively to increase comparability.

$\mathrm{MCE}=\left(\Delta \mathrm{C}_{\mathrm{CO} 2}\right) /\left(\Delta \mathrm{C}_{\mathrm{CO} 2}+\Delta \mathrm{C}_{\mathrm{CO}}\right)$

The particle mass is measured as the collective mass of all particles below a given size limit, shown here as a subscript to $\mathrm{PM}$ (e.g., $\mathrm{PM}_{3.5}$ for particles smaller than $3.5 \mu \mathrm{m}$ ), in analogy with the conventionally defined $\mathrm{PM}_{10}$ and $\mathrm{PM}_{2.5}$.

Linear fitting methods have been used to find relationships between particle emissions and MCE, and between other parameters in the smoke. Following the recommendations of Cantrell (2008), standard linear least squares fitting was used for the parameterization of EF as a function of MCE, whereas the bivariate fitting method described in Cantrell (2008) was used to relate the geometric mean diameter to the geometric standard deviation of the lognormal size distribution of smoke particles. F-statistics has been used to verify relationships found between parameters. From the F-value and the df value, the probability of erroneously finding a relationship between two factors of interest, $P_{\text {err }}$, is calculated using the 
LINEST and FDIST functions of Microsoft EXCEL. For bivariate fittings that minimizes the error in both the $\mathrm{x}$ - and the $y$-direction the error presented is the standard error of the intercept and slope respectively, while for standard fittings that only minimizes the error in the y-direction, the standard error in the y-direction is presented.

\section{Particle size distribution}

Biomass burning emissions are mainly in the accumulation mode, and can be described by a lognormal size distribution (Hinds, 1998; Seinfeld and Pandis, 2006) with a count median diameter, $D_{\mathrm{g}}$ (similar to the geometric mean diameter) and a standard deviation $\sigma_{\mathrm{g}}$. Both $D_{\mathrm{g}}$ and $\sigma_{\mathrm{g}}$ vary with MCE and are interrelated. The fresh smoke arithmetic mean \pm standard deviation is $D_{\mathrm{g}}=(117 \pm 13) \mathrm{nm}$ and the average geometric standard deviation of the particle size distribution is $\sigma_{\mathrm{g}}=1.7 \pm 0.1$ (number of data points in the average, $n=20$, Reid et al., 1998; Guyon et al., 2005; Reid and Hobbs, 1998). Aged smoke particles are larger; $D_{\mathrm{g}}=235 \pm 40 \mathrm{~nm}$, $\sigma_{\mathrm{g}}=1.4 \pm 0.1 \quad(n=14$; Anderson et al., 1996; Fiebig et al., 2003; Formenti et al., 2002; Petzold et al., 2007; Reid et al., 1998).

\subsection{Relationship between $D_{\mathrm{g}}$ and MCE}

Particles emitted during flaming combustion are commonly larger than those emitted during smoldering combustion (Reid and Hobbs, 1998; Hobbs et al., 1996; Rissler et al., 2006; Hays et al., 2002; Wardoyo et al., 2006). Under very strongly smoldering conditions, particles seem to become larger again, but this applies mainly to peat fires at very low combustion efficiencies below 0.7 (Iinuma et al., 2007). The particle size relation to MCE is a linear fit on fresh Brazilian forest smoke (MCE $=0.85-0.98$, age $<4$ min, $n=11$, correlation coefficient $R^{2}=0.83$, Reid and Hobbs, 1998):

$D_{\mathrm{g}} /[\mathrm{nm}]=240 \times \mathrm{MCE}-100$

\subsection{Relationship between $D_{\mathrm{g}}$ and $\sigma_{\mathrm{g}}$}

Figure 1 shows a compilation of published data of $D_{\mathrm{g}}$ and $\sigma_{\mathrm{g}}$ for fresh and aged biomass burning smoke from vegetation fires. Fresh means smoke plumes younger than $\sim 1 \mathrm{~h}$; aged smoke data are mostly from plumes older than one day.

The smoke data have been fitted linearly with a bivariate method (Cantrell, 2008), as errors exist in both $\mathrm{x}$ and $y$ and they co-vary without a causative relationship between $\mathrm{x}$ and $\mathrm{y}$ for fresh, aged, and all data, respectively (Eqs. 3-5). The standard fitting method gives different relations depending on the direction of the fit, i.e., if $D_{\mathrm{g}}$ or $\sigma_{\mathrm{g}}$ is at the x-axis. One of these fits gives approximately the same result as the bivariate fit, while the relation that differs from the bivariate relation gives less variation in $D_{\mathrm{g}}$ with similar variation in $\sigma_{\mathrm{g}}$, see Eqs. (S3-S5) in

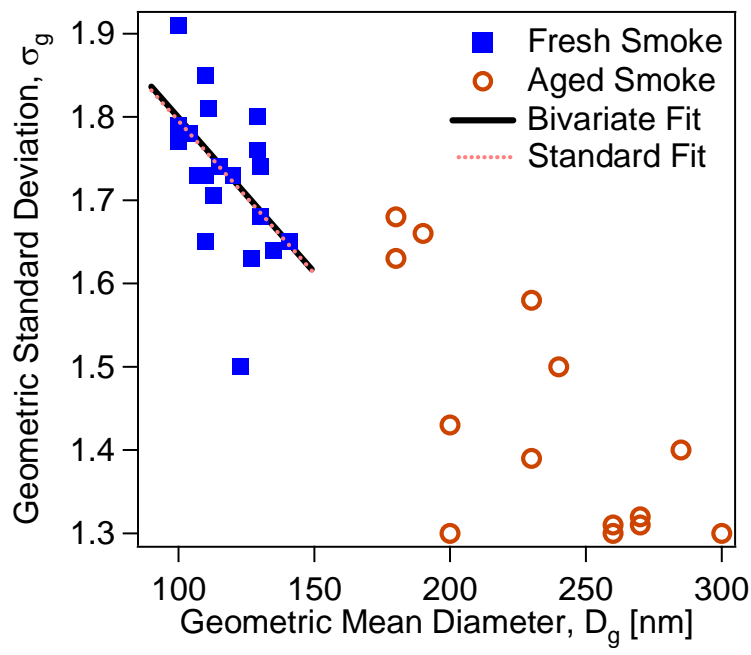

Fig. 1. The geometric mean diameter $\left(D_{\mathrm{g}}\right)$ versus the geometric standard deviation $\left(\sigma_{\mathrm{g}}\right)$ for published fresh and aged smoke data. A bivariate linear fitting method (Cantrell, 2008) has been used on the fresh smoke data, yielding $D_{g} /[\mathrm{nm}]=(584 \pm 5)-(269 \pm 1) \cdot \sigma_{\mathrm{g}}$, Eq. (3), shown as a line. The dotted line is found by fitting the fresh smoke data with the standard regression method. All data are listed in the Supplement (http://www.atmos-chem-phys.net/10/ 1427/2010/acp-10-1427-2010-supplement.pdf).

the Supplement (http://www.atmos-chem-phys.net/10/1427/ 2010/acp-10-1427-2010-supplement.pdf). The correlation between $D_{\mathrm{g}}$ and $\sigma_{\mathrm{g}}$ increases when including data for aged smoke ( $R^{2}=0.30, n=20$, Eq. (3) for fresh smoke, $R^{2}=0.52$, $n=14$, Eq. (4) for aged smoke and $R^{2}=0.80, n=34$, Eq. (5) for the overall data set). The fresh data is the focus of this study and thus Eq. (3) will be used in further analysis, if not stated otherwise.

Fresh: $D_{\mathrm{g}} /[\mathrm{nm}]=(584 \pm 5)-(269 \pm 1) \cdot \sigma_{\mathrm{g}}$

Aged: $D_{\mathrm{g}} /[\mathrm{nm}]=(784 \pm 11)-(382 \pm 1) \cdot \sigma_{\mathrm{g}}$

All data: $D_{\mathrm{g}} /[\mathrm{nm}]=(797 \pm 6)-(392 \pm 1) \cdot \sigma_{\mathrm{g}}$

\section{Particle number emissions}

\subsection{Literature data and average values}

Table 1 gives an overview of studies reporting aerosol particle number emission factors $\left(\mathrm{EF}_{\mathrm{PN}}\right)$ and $\mathrm{CO}$ emission ratios $(\mathrm{PN} / \mathrm{CO})$ from field measurements of biomass burning smoke plumes released by vegetation fires. Very freshly emitted smoke usually contains large amounts of nucleation mode particles with diameters $<30 \mathrm{~nm}$, but they are rapidly lost by coagulation on time scales of minutes and have little influence on the large scale properties and effects of atmospheric aerosols and clouds (Andreae and Rosenfeld, 2008; 
Table 1. Particle number emission data from experimental studies: particle size range, measurement equipment, smoke age, fuel type, modified combustion efficiency, emission factors $\left(\mathrm{EF}_{\mathrm{PN}}\right)$ and emission ratios (PN/CO), only including particles larger than 100-120 nm $\left(\mathrm{PN}_{>100}\right.$, PCASP measurements) or including all particles in the accumulation mode (PN). $n$ is the number of data points and values are tabulated as reported in the cited studies (arithmetic mean \pm standard deviation when available). The Le Canut et al. data of PN $>100$ were extrapolated to PN by assuming the same size distribution as reported by Formenti et al. (extrapolated values in italic). Below the horizontal line the average over the three studies included in the analysis is reported, and the data in the last five lines refer to smoke outside the age range considered in this study, which are included for comparison, but not used any further.

\begin{tabular}{|c|c|c|c|c|c|c|c|c|c|c|}
\hline $\begin{array}{l}\text { Particle diameter } \\
\qquad[\mathrm{nm}]\end{array}$ & Equipment & Age & Fuel & MCE & $\begin{array}{l}\mathrm{EF}_{\mathrm{PN}}>100 \\
{\left[10^{15} \mathrm{~kg}^{-1}\right]}\end{array}$ & $\begin{array}{c}\mathrm{EF}_{\mathrm{PN}} \\
{\left[10^{15} \mathrm{~kg}^{-1}\right]}\end{array}$ & $\begin{array}{c}\mathrm{PN}_{>100} / \mathrm{CO} \\
{\left[\mathrm{cm}^{-3} \mathrm{ppb}^{-1}\right]}\end{array}$ & $\begin{array}{c}\mathrm{PN} / \mathrm{CO} \\
{\left[\mathrm{cm}^{-3} \mathrm{ppb}^{-1}\right]}\end{array}$ & $n$ & References \\
\hline $3-3000$ & $\mathrm{uCPC}$ & $1-30 \mathrm{~min}$ & Savanna & n.a. & n.a. & n.a. & n.a. & $35-45$ & 1 & Hobbs et al. (2003) \\
\hline $5-1000$ & CPC, PCASP & Minutes & Savanna & n.a. & n.a. & n.a. & 26,30 & 51,55 & 2 & Formenti et al. (2003) \\
\hline $8-300$ & $\mathrm{CPC}$ & Minutes & Forest & $0.94 \pm 0.02$ & n.a. & $1.6 \pm 1.0$ & n.a. & $27 \pm 12$ & 34 & Guyon et al. (2005) \\
\hline$>100$ & PCASP & Minutes & Grass & $0.96 \pm 0.01$ & $0.66 \pm 0.32$ & $1.2 \pm 0.6$ & $19 \pm 11$ & $36 \pm 21$ & 9 & Le Canut et al. (1996) \\
\hline$>100$ & PCASP & Minutes & Savanna & $0.97 \pm 0.01$ & $0.67 \pm 0.21$ & $1.3 \pm 0.4$ & $22 \pm 10$ & $46 \pm 14$ & 9 & Le Canut et al. (1996) \\
\hline $10-3000$ & $\mathrm{CPC}$ & Minutes & Forest & $0.93 \pm 0.04$ & n.a. & $3.4 \pm 0.6$ & n.a. & $50 \pm 9$ & 5 & Kuhn et al. (2010) \\
\hline Average & & & All fuels & $0.95 \pm 0.02$ & n.a. & $1.7 \pm 1.2$ & n.a. & $34 \pm 16$ & 57 & $\begin{array}{l}\text { Guyon et al. (2005), } \\
\text { Le Canut et al. (1996), } \\
\text { Kuhn et al. (2010) }\end{array}$ \\
\hline$>3$ & $\mathrm{uCPC}$ & $<1 \min$ & Savanna & $0.94 \pm 0.02$ & n.a. & $31 \pm 19$ & n.a. & $550 \pm 310$ & 4 & Sinha et al. (2003) \\
\hline$>3$ & PCASP & $<1 \min$ & Savanna & $0.95 \pm 0.02$ & $0.21 \pm 0.15$ & n.a. & $4.8 \pm 4.1$ & n.a. & 8 & Sinha et al. (2003) \\
\hline $100-3000$ & PCASP & days & Grass & 0.98 & 0.4 & n.a. & 23 & n.a. & 2 & Anderson et al. (1996) \\
\hline $120-3000$ & PCASP & 10 days & n.a. & n.a. & n.a. & n.a. & n.a. & $12.2^{\mathrm{RH}}$ & 1 & Andreae et al. (1994) \\
\hline$>300$ & LIDAR & Days & n.a. & 0.97 & n.a. & n.a. & n.a. & 17 & 1 & Browell et al. (1996) \\
\hline
\end{tabular}

Hobbs et al., 2003). Thus, the very high EFPN and PN/CO values from studies investigating very fresh smoke within the first few minutes after emission (Table 1: Sinha et al., 2003) are not included in our further analysis. The last three studies listed in Table 1 refer to aged smoke, and also have a rather high lower particle size cutoff $(\sim 120 \mathrm{~nm})$, and are thus not used in the further analysis. The available data is limited to flaming conditions, i.e., MCE larger than 0.9 (the studyaveraged MCEs were between 0.93 and 0.97).

To make the numbers comparable, in spite of the different lower size limits, the Le Canut et al. data is assumed to have the same size distribution and lower particle size cut off as the Formenti et al. data measured in the same area using similar instrumentation. For conversions between the emission ratio $\left[\mathrm{cm}^{-3} \mathrm{ppb}^{-1}\right]$ and the emission factor $\left[\mathrm{kg}^{-1} \mathrm{~d} . \mathrm{m}\right.$. for PN and $\mathrm{g} \mathrm{kg}^{-1}$ d.m. for CO] we assumed $298 \mathrm{~K}$ and $100 \mathrm{kPa}$.

The averaged emission factors for accumulation mode particles, not taking the MCE relationship into account and using size limited corrected overall data, was $(1.7 \pm 1.2) \times$ $10^{15} \mathrm{~kg}^{-1} \mathrm{~d}$.m., with forest fire emission factors of $(1.9 \pm$ 1.3) $\times 10^{15} \mathrm{~kg}^{-1} \mathrm{~d}$.m. The particle number to $\mathrm{CO}$ emission ratios for the overall data set was $34 \pm 16 \mathrm{~cm}^{-3} \mathrm{ppb}^{-1}$, with $30 \pm 14 \mathrm{~cm}^{-3} \mathrm{ppb}^{-1}$ for forest fires, that can be compared to savanna and grass type fuels in Table 1. The data suggests a larger emission factor and a smaller emission ratio for the forest emissions, but the differences between the fuels are within the standard deviation of each measurement, and we cannot show that the difference is real. All data have been assigned to the fuel type reported in the studies referenced; if in doubt the savanna class has been used.

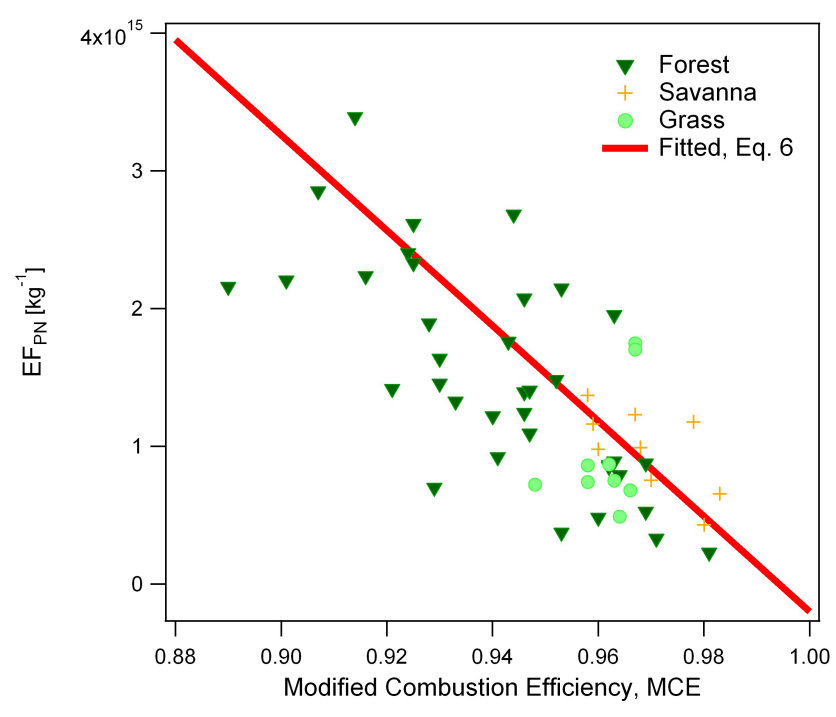

Fig. 2. Particle number emission factors $\left(E_{\mathrm{PN}}\right)$ related to dry mass burned versus modified combustion efficiency (MCE) for three fuel types; forest (Guyon et al., 2005; Kuhn et al., 2010), and savanna and grass (Le Canut et al., 1996). A standard fitting method is used on the overall data set to find $\mathrm{EF}_{\mathrm{PN}} /\left[\mathrm{kg}^{-1}\right]=\left(34.4 \times 10^{15}\right.$ $\left.34.6 \times 10^{15} \times \mathrm{MCE}\right) \pm 0.8 \times 10^{15}$, Eq. (6), shown as a line. Measurements for savanna and grass data used a $\sim 100 \mathrm{~nm}$ particle diameter detection limit and have been corrected as described in Sect. 4.1. 
Table 2. Correlation coefficient $\left(R^{2}\right)$; the F-statistic $(\mathrm{F})$; and the probability that the F-statistic erroneously shows a relation $\left(P_{\text {err }}\right)$ for the emission factor for particle number $\left(\mathrm{EF}_{\mathrm{PN}}\right)$ and the emission ratio $(\mathrm{PN} / \mathrm{CO})$ for the fuel specific data subsets and the overall data. MCE is the modified combustion efficiency averaged over each fuel subset and the overall data is presented as an arithmetic mean \pm standard deviation; $n$ is the number of data points used in the analysis.

\begin{tabular}{lcccccccc}
\hline & \multicolumn{3}{c}{$\mathrm{EF}_{\mathrm{PN}}$} & \multicolumn{3}{c}{$\mathrm{PN} / \mathrm{CO}$} & $\mathrm{MCE}$ & $n$ \\
Fuel & $R^{2}$ & $\mathrm{~F}$ & $P_{\text {err }}$ & $R^{2}$ & $\mathrm{~F}$ & $P_{\text {err }}$ & & \\
\hline Forest & 0.57 & 4 & $10^{-11}$ & 0.07 & 3 & 0.06 & $0.94 \pm 0.02$ & 39 \\
Savanna & 0.45 & 6 & 0.03 & 0.15 & 1 & 0.07 & $0.97 \pm 0.01$ & 9 \\
Grass & 0.20 & 2 & 0.24 & 0.34 & 4 & 0.09 & $0.96 \pm 0.01$ & 9 \\
Overall data & 0.53 & 61 & $10^{-14}$ & 0.00 & 0 & 0.78 & $0.95 \pm 0.02$ & 57 \\
\hline
\end{tabular}

Table 3. Particle mass emission factors, $\mathrm{EF}_{\mathrm{PM}}$, in $\mathrm{g} \mathrm{kg}^{-1} \mathrm{~d}$.m. (arithmetic mean \pm standard deviation) for the three fuel categories separately and the overall data set, and the number of data points in the average, $n, \mathrm{EF}_{\mathrm{PM}}$ calculated using the mean MCE for each fuel subset, in the fuel specific fitted equations (Eqs. 7 to 9), the number of data points in the fits, $n_{\text {fit }}$, compared to previous emission factor reviews.

\begin{tabular}{|c|c|c|c|c|c|c|}
\hline Fuel & $\begin{array}{l}\mathrm{EF}_{\mathrm{PM}}, \text { Average } \\
\quad\left[\mathrm{g} \mathrm{kg}^{-1}\right]\end{array}$ & $n$ & $\begin{array}{c}\mathrm{EF}_{\mathrm{PM}}\left(\mathrm{MCE}_{\text {fueltype }}\right) \\
{\left[\mathrm{g} \mathrm{kg}^{-1}\right]}\end{array}$ & $n_{\text {fit }}$ & $\begin{array}{l}\mathrm{EF}_{\mathrm{PM}} \text {, Reid et al. (2005) } \\
\qquad\left[\mathrm{g} \mathrm{kg}^{-1}\right]\end{array}$ & $\begin{array}{c}\mathrm{EF}_{\mathrm{PM}}, \text { Andreae and Merlet (2001) } \\
{\left[\mathrm{g} \mathrm{kg}^{-1}\right]}\end{array}$ \\
\hline Forest & $9.6 \pm 4.6$ & 21 & $11.5 \pm 4.5$ & 12 & $15 \pm 11^{b}$ & $10 \pm 3^{\mathrm{d}}$ \\
\hline Savanna & $6.3 \pm 3.0$ & 24 & $6.3 \pm 2.0$ & 24 & $8 \pm 2^{\mathrm{b}}$ & \\
\hline Grass & $4.7 \pm 2.1$ & 15 & $5.1 \pm 1.9$ & 14 & $7 \pm 2^{\mathrm{b}}$ & $5 \pm 2$ \\
\hline Overall data & $7.6 \pm 4.7$ & 61 & $7.6 \pm 3.4$ & 50 & & $7 \pm 2^{\mathrm{c}}$ \\
\hline
\end{tabular}

a Averaged over the available data, not taking burned amount into consideration.

b Given with "absolute uncertainty" instead of standard deviation.

c Average weighted with burned mass (Andreae and Merlet, 2001).

d Average over two different kinds of forests, weighted with burned mass (Andreae and Merlet, 2001).

\subsection{Dependence on combustion efficiency}

The possibility of an MCE effect on the emission factor is tested by F-statistics. The emission factor for the overall data set, $\mathrm{EF}_{\mathrm{PN}}$, shows a linear relationship to MCE, as does the emission factor for forest fuel (Table 2). Grass and savanna fuels are less conclusive, but point towards the same conclusion, i.e., a relationship between $\mathrm{MCE}$ and $\mathrm{EF}_{\mathrm{PN}}$ (Table 2), even though it is a small data set, with a 100 $\mathrm{nm}$ lower size limit, and a small variation in MCE (from 0.95 to 0.98 ). On the other hand, there is no relationship between MCE and the CO-referenced particle emission ratios for the overall data set, while the fuel specific ratios are inconclusive (Table 2). We thus conclude that there is a linear relationship between $\mathrm{EF}_{\mathrm{PN}}$ and $\mathrm{MCE}$, but no relationship between PN/CO and MCE. The spread in the $\mathrm{PN} / \mathrm{CO}$ ratios and the lack of a MCE relationship is shown in Fig. S1 in Supplement (http://www.atmos-chem-phys.net/ 10/1427/2010/acp-10-1427-2010-supplement.pdf).

$\mathrm{EF}_{\mathrm{PN}} /\left[\mathrm{kg}^{-1}\right]=34.4 \times 10^{15}-34.6 \times 10^{15} \times \mathrm{MCE} \pm 0.8 \times 10^{15}(6)$

Standard fitting methods were applied to the combined data set (corrected for the $100 \mathrm{~nm}$ size limit) from grass, savanna, and forest fires (Eq. 6, Fig. 2), where most of the data are from flaming conditions (MCE >0.9) (Le Canut et al., 1996; Guyon et al., 2005; Kuhn et al., 2010). The fittings applied only to the forest fuel data is shown in Eqs. (S6) and (S7) in the Supplement (http://www.atmos-chem-phys.net/10/1427/ 2010/acp-10-1427-2010-supplement.pdf).

\section{Particle mass emissions}

\subsection{Literature data and average values}

Particle mass emission data is frequently used in models and is more abundant than particle number emission data, but the upper particle size limit varies between the published data sets. We focus on the accumulation mode and thus, the upper particle size limit should be between the accumulation mode and the coarse mode, i.e., around one micrometer in diameter (Fuzzi et al., 2007; Reid et al., 2005).

Here data with an upper particle size limit of $1 \mu \mathrm{m}$, $\mathrm{PM}_{1}$, are used together with $\mathrm{PM}_{2.5}$ data, thus the analysis of the MCE relationship is then based on 50 instead of only the 4 available $\mathrm{PM}_{1}$ data points, and the average $\mathrm{EF}_{\mathrm{PM}}$ is based on 61 instead of 11 data points (Battye and 
Table 4. Emission ratio (PM/CO) and emission factor for particle mass (EFPM) for the overall data set and the fuel specific data subsets as an arithmetic mean \pm standard deviation. Both variables are presented with the correlation coefficient $\left(R^{2}\right)$; the F-statistic $(\mathrm{F})$; and the probability that the F-statistic erroneously shows a relation $\left(P_{\text {err }}\right) \cdot \mathrm{CO}_{\text {calc }}$ is the fraction of the data where $\mathrm{CO}$ emissions were not reported and thus calculated as described in the text; MCE is the modified combustion efficiency averaged over each fuel subset and the overall data, $n$ is the number of data points used in the analysis and $n_{\mathrm{S}}$ the number of published studies used.

\begin{tabular}{|c|c|c|c|c|c|c|c|c|c|c|c|c|}
\hline Fuel & $\begin{array}{c}\mathrm{EF}_{\mathrm{PM}} \\
{\left[\mathrm{g} \mathrm{kg}^{-1}\right]}\end{array}$ & $R^{2}$ & $\mathrm{~F}$ & $P_{\text {err }}$ & $\begin{array}{l}\mathrm{PM} / \mathrm{CO} \\
{\left[\mathrm{g} \mathrm{g}^{-1}\right]}\end{array}$ & $R^{2}$ & $\mathrm{~F}$ & $P_{\text {err }}$ & $\mathrm{CO}_{\text {calc }}$ & MCE & $n$ & $n_{\mathrm{s}}$ \\
\hline Forest & $11 \pm 6$ & 0.60 & 15 & $10^{-3}$ & $0.13 \pm 0.05$ & 0.27 & 4 & 0.06 & 0.42 & $0.91 \pm 0.05$ & 12 & 4 \\
\hline Savanna & $6 \pm 3$ & 0.33 & 11 & $4 \times 10^{-4}$ & $0.08 \pm 0.03$ & 0.05 & 1 & 0.37 & 0 & $0.93 \pm 0.03$ & 24 & 4 \\
\hline Grass & $5 \pm 2$ & 0.74 & 34 & $10^{-5}$ & $0.07 \pm 0.03$ & 0.15 & 2 & 0.16 & 0.13 & $0.93 \pm 0.03$ & 14 & 3 \\
\hline Overall data & $7 \pm 4$ & 0.48 & 44 & $2 \times 10^{-11}$ & $0.09 \pm 0.04$ & 0.05 & 3 & 0.08 & 0.14 & $0.92 \pm 0.04$ & 50 & 9 \\
\hline
\end{tabular}

Battye, 2002; Dhammapala et al., 2007; Kaufman et al., 1992; Korontzi et al., 2003; Scholes et al., 1996; Ward et al., 1991, 1992; Ward and Hardy, 1991; Ward, 1996; Yokelson et al., 2007; Formenti et al., 2003; Martins et al., 1996), with the two last references excluding MCE. Data reported without relation to MCE is used only in the calculation of the arithmetic mean \pm standard deviation of $\mathrm{EF}_{\mathrm{PM}}$, resulting in an $\mathrm{EF}_{\mathrm{PM}}$ for the overall data of (7.6 \pm 4.7$) \mathrm{g} \mathrm{kg}^{-1}$ d.m., with larger emissions for forest fuels and smaller emissions for savanna and grass fuels (Table 3). The average PM/CO emission ratio is $(0.09 \pm 0.04) \mathrm{g} \mathrm{g}^{-1}$ for the overall data, with similar fuel effects as for $\mathrm{EF}_{\mathrm{PM}}$, giving emission ratios of $\mathrm{PM} / \mathrm{CO}=(0.13 \pm 0.05) \mathrm{g} \mathrm{g}^{-1}$ for forest; $\mathrm{PM} / \mathrm{CO}=(0.08 \pm 0.03) \mathrm{g} \mathrm{g}^{-1}$ for savanna; and $\mathrm{PM} / \mathrm{CO}=(0.07 \pm 0.03) \mathrm{g} \mathrm{g}^{-1}$ for grass. All analyses shown here have been repeated on datasets including also $\mathrm{PM}_{3.5}$, $\mathrm{PM}_{4}$ and $\mathrm{PM}_{0.5}$ data to show the limited effect resulting from adding data with slightly different particle size limits (The analysis on an extended data set including $\mathrm{PM}_{0.5}$ up to $\mathrm{PM}_{4}$ is shown in Supplement: http://www.atmos-chem-phys.net/ 10/1427/2010/acp-10-1427-2010-supplement.pdf).

The $\mathrm{EF}_{\mathrm{PM}}$ obtained in this study, both as direct fuel specific averages and calculated using the equations obtained below (Eqs. 7-10) with fuel specific MCE averages, are similar to other published non-parameterized PM emission factors, Table 3.

\subsection{Dependence on combustion efficiency}

F-statistics analysis in Table 4 shows a high F-statistic and a low $P_{\text {err }}$ for the emission factor implicating that $\mathrm{EF}_{\mathrm{PM}}$ is MCE dependent, while the low F-statistic and high $P_{\text {err }}$ for the emission ratio shows that the $\mathrm{PM} / \mathrm{CO}$ emission ratio has no MCE dependence. In some studies, the $\mathrm{CO}$ emission factor, needed to calculate the $\mathrm{PM} / \mathrm{CO}$ ratio, is not given and the MCE together with an estimated $\mathrm{CO}_{2}$ emission factor of $1580 \mathrm{~g} \mathrm{~kg}^{-1}$ d.m.(Andreae and Merlet, 2001) is used to calculate the $\mathrm{CO}$ emission factor. The fraction of the data treated this way is between 0 and 0.42 for the different fuel types (Table 4).

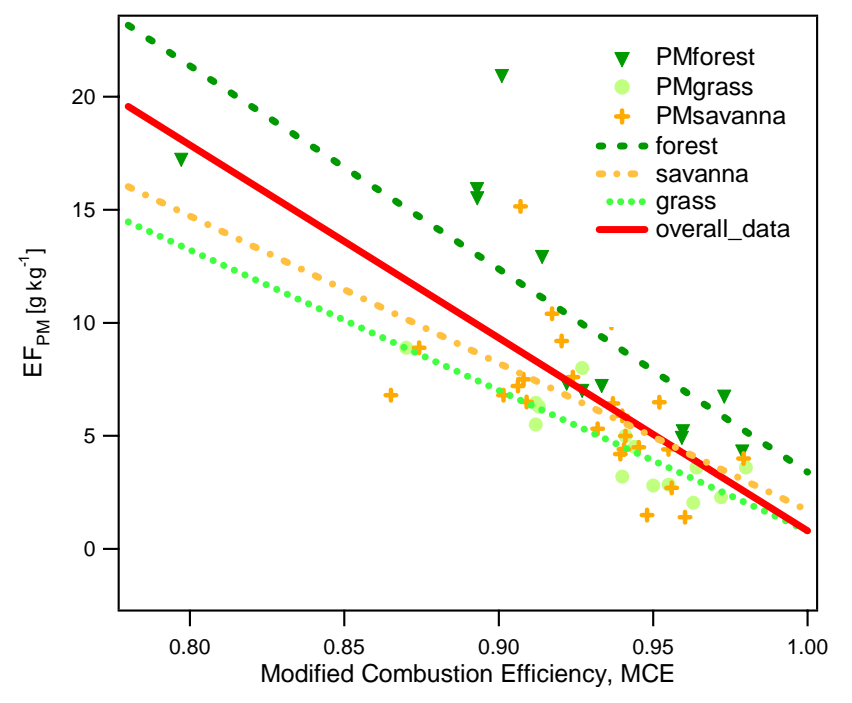

Fig. 3. Particle mass emission factors $\left(E_{P M}\right)$ related to dry mass burned versus modified combustion efficiency (MCE) for three fuel types from ten different studies, with the fitted equations for each of the fuel types and for the overall data set $\left(\mathrm{EF}_{\mathrm{PM}}\right.$,forest $/\left[\mathrm{g} \mathrm{kg}^{-1}\right]=(93.2-89.8 \times \mathrm{MCE}) \pm 3.8$, for forest, $\mathrm{EF}_{\mathrm{PM} \text {,savanna }} /\left[\mathrm{g} \mathrm{kg}^{-1}\right]=(66.8-65.1 \times \mathrm{MCE}) \pm 2.5$ for savanna, $\mathrm{EF}_{\mathrm{PM} \text {, grass }} /\left[\mathrm{g} \mathrm{kg}^{-1}\right]=(62.9-62.1 \times \mathrm{MCE}) \pm 1.1$, for grass and $\mathrm{EF}_{\mathrm{PM} \text {,overall }} /\left[\mathrm{g} \mathrm{kg}^{-1}\right]=(86.1-85.3 \times \mathrm{MCE}) \pm 3.1$ for the overall data set, Eqs. 7-10) shown as lines.

Figure 3 shows the EFPM vs. MCE data, with most of the available data from flaming combustion. The $\mathrm{EF}_{\mathrm{PM}}$ to MCE standard linear fits for the different fuel types (Eqs. 79) and for the overall data set (Eq. 10) are shown as lines. The forest fire emission factors are higher than the emissions for savanna and grass fires. The overall data fit has a larger slope than the fuel specific fits possibly influenced by the high emitting - low MCE forest fuels combined with the low emitting - high MCE grass/savanna fuels. The higher $\mathrm{EF}_{\mathrm{PM}}$ for forest type fuels is a combined result of both higher $\mathrm{EF}_{\mathrm{PM} \text {,forest }}(\mathrm{MCE})$ and lower MCE in the forest case. 


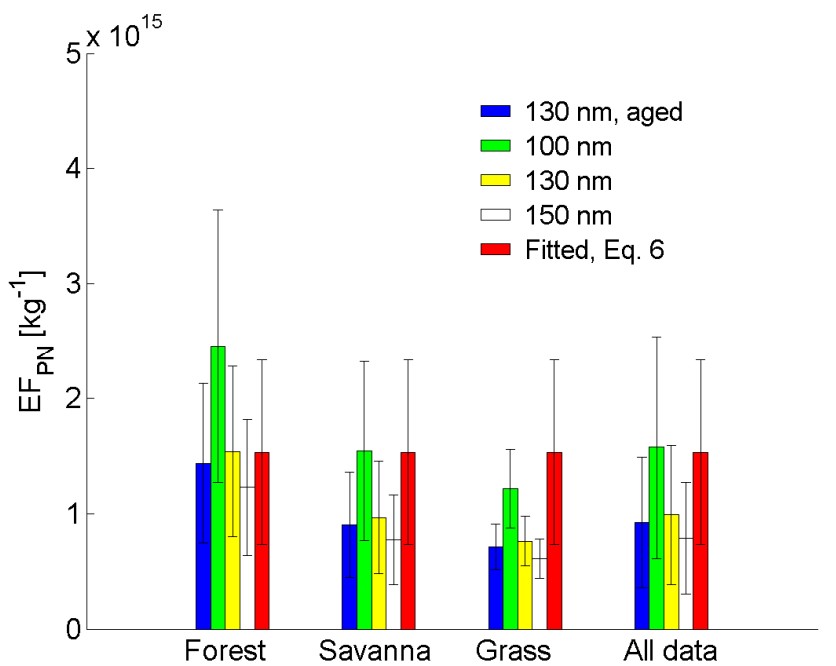

Fig. 4. Particle number emission factors $\left(\mathrm{EF}_{\mathrm{PN}}\right)$ related to dry mass burned, calculated from $\mathrm{EF}_{\mathrm{PM}}$ at $\mathrm{MCE}=0.95$ for the different fuel types, Eqs. (7-10), using different particle diameters $\left(D_{\mathrm{g}}\right)$ given in the legend. The geometric mean diameter $D_{\mathrm{g}}$ is related to the geometric standard deviation $\sigma_{\mathrm{g}}$ using Eq. (3), apart from the " $130 \mathrm{~nm}$, aged" case, where the fit to the aged data set, Eq. (4), is used. The calculated $E_{P N}$ for different particle sizes are compared to the measurement-based fitted equation, $\mathrm{EF}_{\mathrm{PN}} /\left[\mathrm{kg}^{-1}\right]=\left(34.4 \times 10^{15}-34.6 \times 10^{15} \times \mathrm{MCE}\right) \pm 0.8 \times 10^{15}$, Eq. (6), at $\mathrm{MCE}=0.95$. The error bars are based on the standard error of the fits for $\mathrm{EF}_{\mathrm{PM}} \mathrm{vs.} \mathrm{MCE}$ and $\mathrm{EF}_{\mathrm{PN}}$ vs. MCE, respectively.

$\mathrm{EF}_{\mathrm{PM}, \text { forest }} /\left[\mathrm{g} \mathrm{kg}^{-1}\right]=93.2-89.8 \times \mathrm{MCE} \pm 3.8$

$\mathrm{EF}_{\mathrm{PM} \text {,savanna }} /\left[\mathrm{g} \mathrm{kg}^{-1}\right]=66.8-65.1 \times \mathrm{MCE} \pm 2.5$

$\mathrm{EF}_{\mathrm{PM}, \text { grass }} /\left[\mathrm{g} \mathrm{kg}^{-1}\right]=62.9-62.1 \times \mathrm{MCE} \pm 1.1$

$\mathrm{EF}_{\mathrm{PM}, \text { overall }} /\left[\mathrm{g} \mathrm{kg}^{-1}\right]=86.1-85.3 \times \mathrm{MCE} \pm 3.1$

The standard linear fitting has been performed on some 30 published studies individually, giving similar linear fits as the ones obtained here (Table S4 in Supplement: http://www.atmos-chem-phys.net/10/1427/2010/ acp-10-1427-2010-supplement.pdf). We conclude that MCE is an important variable to describe the particle mass emissions from vegetation fires.

\section{Particle number emission factors derived from parti- cle mass emission factors}

The following closure study is used to determine which parameters contribute most to the uncertainty, as the available emission data on particle number, particle size distribution and particle mass is rather sparse. We compare the measurement-based fitted particle number emission factor, Eq. (6), to the particle number emission factors calculated

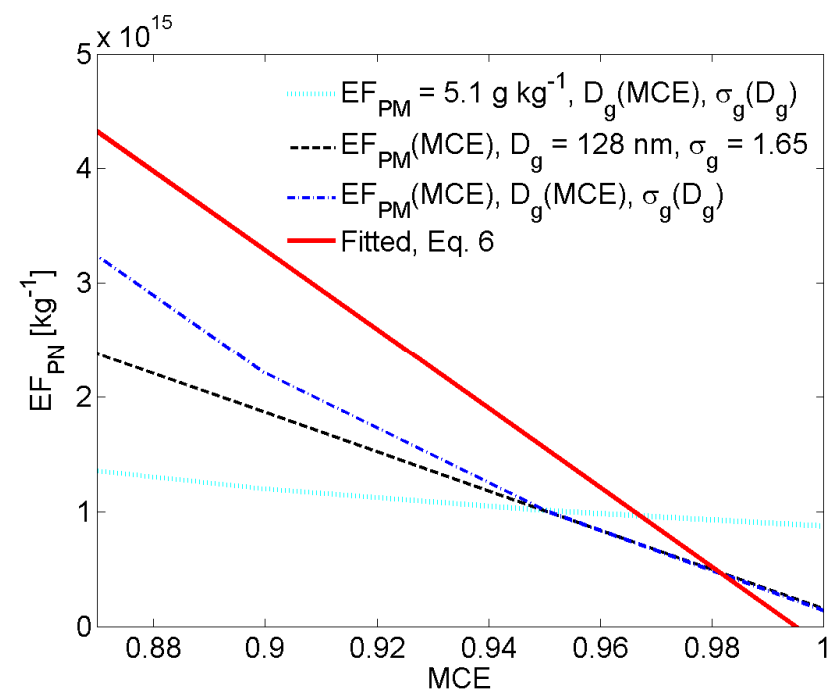

Fig. 5. Particle number emission factors $\left(\mathrm{EF}_{\mathrm{PN}}\right)$ related to dry mass burned versus modified combustion efficiency (MCE), calculated from the particle mass emission factor for the overall data set $\left(\mathrm{EF}_{\mathrm{PM} \text {,overall }}\right) . \mathrm{EF}_{\mathrm{PM} \text {, overall }}$ is either constant at $\mathrm{MCE}=0,95$; $\mathrm{EF}_{\mathrm{PM} \text {, overall }}=5.1 \mathrm{~g} \mathrm{~kg}^{-1} \mathrm{~d}$.m., or varied with MCE, Eq. (10). The particle sizes are either constant at $\mathrm{MCE}=0.95 ; D_{\mathrm{g}}=128 \mathrm{~nm}$ and $\sigma_{\mathrm{g}}=1.65$, or varied with MCE, Eqs. (2-3).

using $\mathrm{EF}_{\mathrm{PM}}$, Eqs. (7-10), combined with different assumptions, mainly Eqs. (2) and (3) for size distribution. The particle density is assumed not to vary with MCE, and is set to $1300 \mathrm{~kg} \mathrm{~m}^{-3}$ (Reid et al., 2005).

\subsection{Average $\mathbf{E F}_{\mathrm{PN}}$}

To visualize the particle size impact on the calculated $\mathrm{EF}_{\mathrm{PN}}$, $\mathrm{EF}_{\mathrm{PM}}$ is calculated for each fuel, using Eqs. (7-10) at the average MCE over all particle number emission data, MCE $=0.95$ (Table 1). Three different values of $D_{\mathrm{g}}$ are used ( $D_{\mathrm{g}}=100,130$ or $150 \mathrm{~nm}$, Reid et al., 2005), and the $D_{\mathrm{g}}$ to $\sigma_{\mathrm{g}}$ relationship for fresh particles, Eq. (3), is used. To visualize the impact from $\sigma_{\mathrm{g}}$, one case using the aged data set fit, Eq. (4), is added. The effect from this change is a $20 \%$ decrease in $\mathrm{EF}_{\mathrm{PN}}$, Fig. 4.

A decrease in particle diameter $D_{\mathrm{g}}$ from 150 to $100 \mathrm{~nm}$ almost doubles the particle number emissions (Fig. 4), including the minor effect related to changing $\sigma_{\mathrm{g}}$ with $D_{\mathrm{g}}$, Eq. (3). The particle number emission factors calculated from particle mass data compare best to the directly measured $\mathrm{EF}_{\mathrm{PN}}$, when using a diameter of $\sim 140 \mathrm{~nm}$ for forest fire particles and $100 \mathrm{~nm}$ for grass fire particles (Fig. 4). This is in accordance with, e.g., Reid et al., 2005, where the grass/savanna fuel particles give an average $D_{\mathrm{g}}$ of $110 \mathrm{~nm}$, while forest fires give $140 \mathrm{~nm}$, suggesting that forest fire particles are larger than grass fire particles. This difference might be even larger taking the MCE effect on particle size into account. 

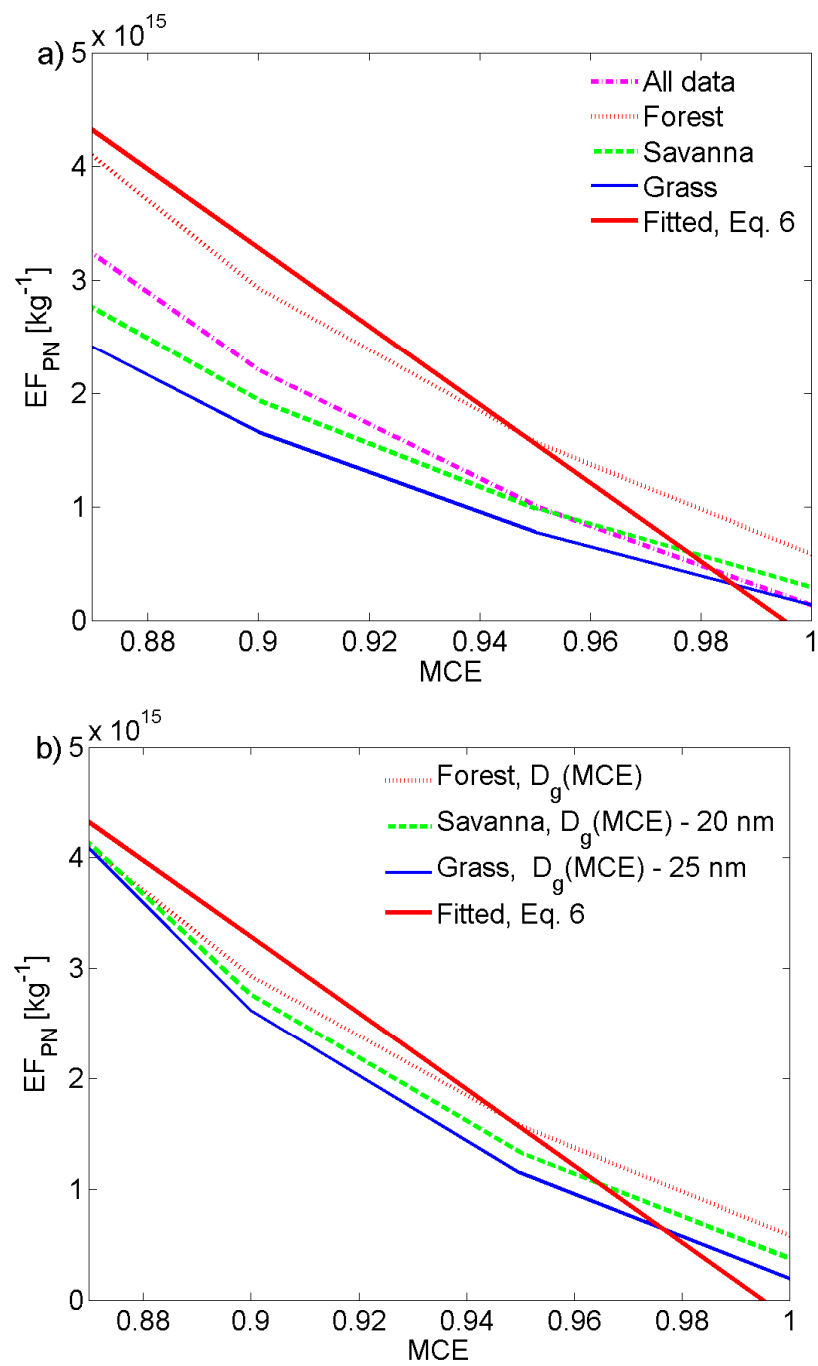

Fig. 6. Particle number emission factors $\left(\mathrm{EF}_{\mathrm{PN}}\right)$ related to dry mass burned versus modified combustion efficiency (MCE) for different fuels. The calculations from $\mathrm{EF}_{\mathrm{PM}}$ data are based on varying $\mathrm{EF}_{\mathrm{PM}}$ with fuel and MCE, Eqs. (7-10), and the particle sizes with MCE Eqs. (2-3). (a) No particle size difference between fuels is assumed. (b) The particle size has been reduced for grass emissions by $25 \mathrm{~nm}$ and for savanna emissions by $20 \mathrm{~nm}$, in accordance with Reid et al. (2005).

\subsection{MCE dependent $\mathrm{EF}_{\mathrm{PN}}$}

A number of different assumptions are used to calculate the MCE dependent $\mathrm{EF}_{\mathrm{PN}}$ from $\mathrm{EF}_{\mathrm{PM}}$, as $\mathrm{EF}_{\mathrm{PM}}$ divided by the average particle mass gives $\mathrm{EF}_{\mathrm{PN}}$. The mean diameter, $D_{\mathrm{p}}$, is calculated from the median diameter using the lognormal assumption to get $D_{\text {mean }}=D_{\mathrm{p}} \times e^{1.5 \times \sigma^{2}}$ (Hinds, 1998). In Fig. 5, $\mathrm{EF}_{\mathrm{PM} \text {,overall }}$ (Eq. 10) is used as a basis for the calculation of $\mathrm{EF}_{\mathrm{PN}}$, and it is evident that the measured $\mathrm{EF}_{\mathrm{PN}}$ is most similar to the calculated $\mathrm{EF}_{\mathrm{PN}}$ when both $\mathrm{EF}_{\mathrm{PM}}$ (Eq. 10), and the particle size distribution are allowed to vary with MCE
(Eqs. 2-3). A much poorer fit is obtained when either parameter is held constant at $\mathrm{MCE}=0.95$, i.e., the average combustion efficiency of the $\mathrm{EF}_{\mathrm{PN}}$ data presented in Table 1. Results obtained with a wider range of assumptions are shown in the Supplement (http://www.atmos-chem-phys.net/10/1427/ 2010/acp-10-1427-2010-supplement.pdf).

In Fig. 6a the fuel dependent particle mass emission factors (Eqs. 7-10) are used to calculate $\mathrm{EF}_{\mathrm{PN}}$ for each fuel, while the particle size varies only with MCE and not fuel type, even though this was suggested in Fig. 5 and in Reid et al. (2005b). Keeping the size variation with MCE while introducing a fuel related size difference, we assume that grass particles are $25 \mathrm{~nm}$ and savanna particles are $20 \mathrm{~nm}$ smaller than in Eq. (2). The result is shown in Fig. 6b, where the emission factors for different fuels mainly collapse onto one line, following the results in Table 1, where no fuel effect on particle number emissions was found. This suggests that the fuel effect on particle mass emissions might solely result from particle size effects, with similar particle number emissions for all fires.

\section{$\begin{array}{ll}7 & \mathbf{E F}_{\mathrm{PN}} \text { estimate for coarse particles }\end{array}$}

For completeness, the particle number emission factor has also been defined for coarse particles, $\mathrm{EF}_{\mathrm{PN}, \mathrm{c}}$, calculated both through the number ratio, and through the mass ratio, between the accumulation and coarse modes given in the literature. All parameters referring to the coarse mode were defined and determined in analogy with the accumulation mode parameters, but with " $\mathrm{c}$ " as an index. For the coarse particle emissions a relationship to MCE could not be established.

Table 5 gives a literature overview of number concentration ratios between the coarse and accumulation mode, with a median number ratio of $10^{-4}$, i.e., the number of coarse particles emitted is 10000 times smaller than the number of accumulation mode particles. If $\mathrm{EF}_{\mathrm{PN}}$ for accumulation mode particles equals $10^{15} \mathrm{~kg}^{-1} \mathrm{~d}$.m. (Table 1) the $\mathrm{EF}_{\mathrm{PN}, \mathrm{c}}$ for coarse particles would be $10^{11} \mathrm{~kg}^{-1}$ d.m. The mass median ratio of $\mathrm{EF}_{\mathrm{PM}, \mathrm{c}}$ and $\mathrm{EF}_{\mathrm{PM}}$ from Table 5 is $0.2 \pm 0.1$, which together with the average $\mathrm{EF}_{\mathrm{PM}}$ of the overall data $(7.6 \pm 4.7) \mathrm{g} \mathrm{kg}^{-1}$ d.m. gives an approximate $\mathrm{EF}_{\mathrm{PM}, \mathrm{c}}$ of $1.5 \mathrm{~g} \mathrm{~kg}^{-1} \mathrm{~d} . \mathrm{m}$.

The $\mathrm{EF}_{\mathrm{PM}, \mathrm{c}}$ estimate is given without fuel differences, both due to scarce available data and because a smaller effect of fuel on coarse particle emissions is assumed, based on simple calculations. We know from the literature that grass fires emit a larger proportion of coarse particles than forest fires (Reid et al., 2005; Schafer et al., 2008; Andreae and Merlet, 2001). For the ratio between $\mathrm{EF}_{\mathrm{PM}}$ and $\mathrm{EF}_{\mathrm{PM}, \mathrm{c}}$ we use the ratio between the emissions of total suspended particles (TSP) and $\mathrm{PM}_{2.5}$ of 0.35 for forest and 0.54 for savanna/grassland (Andreae and Merlet, 2001), as an upper estimate compared to the other data in Table 5. Using these ratios and the $\mathrm{EF}_{\mathrm{PM}}$ 
Table 5. The ratio of coarse to accumulation mode particle concentrations from different studies is given both as number ratios and mass ratios $\left(\mathrm{PN}_{\mathrm{c}} / \mathrm{PN} ; \mathrm{PM}_{\mathrm{c}} / \mathrm{PM}\right)$, together with the approximate peak particle size for the coarse particle mode for number size distributions $\left(D_{\mathrm{g}, \mathrm{c}}\right)$ and for mass size distributions $\left(D_{\mathrm{g}, \mathrm{c}, \mathrm{M}}\right)$, where available. The fuel, or site of the burn is given in the last column and the median of the data in the last row.

\begin{tabular}{lccccl}
\hline Cite & $\mathrm{PN}_{\mathrm{c}} / \mathrm{PN}$ & $\mathrm{PM}_{\mathrm{c}} / \mathrm{PM}$ & $D_{\mathrm{g}, \mathrm{c}}[\mu \mathrm{m}]$ & $D_{\mathrm{g}, \mathrm{c}, \mathrm{M}}[\mu \mathrm{m}]$ & Fuel or site etc. \\
\hline Andreae et al. (1994) & $2.00 \mathrm{E}-05$ & & & & savanna, forest \\
Hungershoefer et al. (2008) & $1.00 \mathrm{E}-04$ & & 4 & & lab, grass \\
Hungershoefer et al. (2008) & $1.00 \mathrm{E}-04$ & & $2-3$ & & lab, musasa \\
Haywood et al. (2003) & $1.00 \mathrm{E}-04$ & & 3 & & Otavi plume \\
Radke et al. (1991) & $1.00 \mathrm{E}-06$ & & $<10$ & & voreal forest \\
Petzold et al. (2007) & $2.00 \mathrm{E}-04$ & & $1-2$ & & savanna, grass \\
Le Canut et al. (1996) & $1.00 \mathrm{E}-04$ & & $>3$ & 3 & Brazil, all fuels \\
Reid and Hobbs (1998) & $2.00 \mathrm{E}-05$ & 0.1 & 1.5 & 10 & lab, agriculture \\
Keshtkar and Ashbaugh (2007) & & 0.15 & & $4-5$ & Brazil \\
Fuzzi et al. (2007) & & 0.2 & & 5 & Brazil \\
Fuzzi et al. (2007) & & 0.1 & & 1.5 & aged, peat and forest \\
Eck et al. (2003) & & 0.14 & & $5-10$ & forest \\
Eck et al. (2003) & & 0.1 & & 7 & grass \\
Eck et al. (2003) & & 0.54 & & & grass/savanna \\
Andreae and Merlet (2001) & & 0.35 & & & forest \\
Andreae and Merlet (2001) & & 0.3 & & & grass/savanna \\
Ward et al. (2006) & & & & \\
\hline Median & & 0.2 & & \\
\hline
\end{tabular}

Table 6. The different $\mathrm{EF}_{\mathrm{PN}, \mathrm{c}}$ calculated with three different assumptions about the ratio between particle mass concentrations in the coarse and accumulation modes $\left(\sim 10 \%, \sim 30 \%\right.$ and $\sim 50 \%$ of $\left.\mathrm{EF}_{\mathrm{PM}}\right)$, three different $D_{\mathrm{g}, \mathrm{c}}(1,3$, or $5 \mu \mathrm{m})$ and three different $\sigma_{\mathrm{g}, \mathrm{c}}$ (1.6, 1.8, or 2.0). The $D_{\mathrm{g}, \mathrm{c}, \mathrm{M}}$ are calculated from $D_{\mathrm{g}, \mathrm{c}}$ and $\sigma_{\mathrm{g}, \mathrm{c}}$ using the Hatch-Choate equations (e.g., Hinds, 1998). All cases use $\mathrm{EF}_{\mathrm{PM} \text {, overall }}=7.6 \pm 3.4 \mathrm{~g} \mathrm{~kg}^{-1} \mathrm{~d} . \mathrm{m}$. for the accumulation mode particle mass emission factor for the overall data set.

\begin{tabular}{cccccc}
\hline $\begin{array}{c}D_{\mathrm{g}, \mathrm{c}} \\
{[\mu \mathrm{m}]}\end{array}$ & $\sigma_{\mathrm{g}, \mathrm{c}}$ & $\begin{array}{c}D_{\mathrm{g}, \mathrm{c}, \mathrm{M}} \\
{[\mu \mathrm{m}]}\end{array}$ & & $\mathrm{EF}_{\mathrm{PN}, \mathrm{c}}\left[10^{9} \mathrm{~kg}^{-1}\right]$ & \\
\hline & & & $\mathrm{EF}_{\mathrm{PM}, \mathrm{c}}=1 \mathrm{~g} \mathrm{~kg}^{-1}$ & $\mathrm{EF}_{\mathrm{PM}, \mathrm{c}}=2.5 \mathrm{~g} \mathrm{~kg}^{-1}$ & $\mathrm{EF}_{\mathrm{PM}, \mathrm{c}}=4 \mathrm{~g} \mathrm{~kg}^{-1}$ \\
\hline 1 & 1.6 & 2 & $5.4 \mathrm{E}+02$ & $1.4 \mathrm{E}+03$ & $2.2 \mathrm{E}+03$ \\
1 & 1.8 & 3 & $3.1 \mathrm{E}+02$ & $7.8 \mathrm{E}+02$ & $1.2 \mathrm{E}+03$ \\
1 & 2.0 & 4 & $1.7 \mathrm{E}+02$ & $4.2 \mathrm{E}+02$ & $6.8 \mathrm{E}+02$ \\
3 & 1.6 & 6 & $2.0 \mathrm{E}+01$ & $5.0 \mathrm{E}+01$ & $8.1 \mathrm{E}+01$ \\
3 & 1.8 & 8 & $1.2 \mathrm{E}+01$ & $2.9 \mathrm{E}+01$ & $4.6 \mathrm{E}+01$ \\
3 & 2.0 & 13 & $6.3 \mathrm{E}+00$ & $1.6 \mathrm{E}+01$ & $2.5 \mathrm{E}+01$ \\
5 & 1.6 & 10 & $4.4 \mathrm{E}+00$ & $1.1 \mathrm{E}+01$ & $1.7 \mathrm{E}+01$ \\
5 & 1.8 & 14 & $2.5 \mathrm{E}+00$ & $6.2 \mathrm{E}+00$ & $9.9 \mathrm{E}+00$ \\
5 & 2.0 & 21 & $1.4 \mathrm{E}+00$ & $3.4 \mathrm{E}+00$ & $5.4 \mathrm{E}+00$ \\
\hline
\end{tabular}

calculated using Eqs. (7) to (9) at fuel-dependent averaged MCE (Table 3), we obtain an EFPM,c for the different fuels between 3 and $4 \mathrm{~g} \mathrm{~kg}^{-1}$ d.m. $\left(0.54 \times 5.1=2.8 \mathrm{~g} \mathrm{~kg}^{-1} \mathrm{~d} . \mathrm{m}\right.$. for grass, $0.54 \times 6.3=3.1 \mathrm{~g} \mathrm{~kg}^{-1} \mathrm{~d} . \mathrm{m}$. for savanna and $0.35 \times 11.5=4.0 \mathrm{~g} \mathrm{~kg}^{-1} \mathrm{~d} . \mathrm{m}$. for forest) showing a lower effect from fuel for the coarse particles as compared to the accumulation mode particles.
To calculate the $\mathrm{EF}_{\mathrm{PN}, \mathrm{c}}$ from $\mathrm{EF}_{\mathrm{PM}, \mathrm{c}}$ we exemplify $\mathrm{EF}_{\mathrm{PM}, \mathrm{c}}$ to be $1,2.5$, or $4 \mathrm{~g} \mathrm{~kg}^{-1} \mathrm{~d} . \mathrm{m}$., and use different assumptions for the particle size distribution. The peak particle size is lower for number size distributions, $D_{\mathrm{g}, \mathrm{c}}$, than for mass size distributions, $D_{\mathrm{g}, \mathrm{c}, \mathrm{M}}$ (Table 5 and Hatch-Choate equations found, e.g., in Hinds, 1998), and is exemplified with 1, 3 or $5 \mu \mathrm{m}$. For $\sigma_{\mathrm{g}, \mathrm{c}} 1.6,1.8$ and 2.0 are used, as 1.6 is calculated from $D_{\mathrm{g}, \mathrm{c}}$ and $D_{\mathrm{g}, \mathrm{c}, \mathrm{M}}$ in Reid and Hobbs (1998) (Table 5) 
while 2.0 describes the dust mode in the ECHAM model (Stier et al., 2005), and Haywood et al. (2003) used a $\sigma_{\mathrm{g}, \mathrm{c}}$ of $1.9 \pm 0.4$ for the biomass coarse mode.

Table 6 shows the resulting $\mathrm{EF}_{\mathrm{PN}, \mathrm{c}}$ to be between $10^{9}$ and $10^{12} \mathrm{~kg}^{-1} \mathrm{~d} . \mathrm{m}$., and a median value of $2 \times 10^{10} \mathrm{~kg}^{-1} \mathrm{~d} . \mathrm{m}$. The value of $\mathrm{EF}_{\mathrm{PN}, \mathrm{c}}=2 \times 10^{10} \mathrm{~kg}^{-1} \mathrm{~d}$.m. for the particle mass ratio agrees fairly well with $E_{P N, c}=10^{11} \mathrm{~kg}^{-1}$ d.m. from the particle number ratio, keeping the large uncertainty in the input in mind.

\section{Conclusions and outlook}

We have used published data on aerosol particle number and mass emissions from vegetation fires to calculate dynamic emission factors, as a function of MCE for different fuel types. Emission factors and size distribution parameters for both accumulation and coarse mode particles are presented in relation to MCE, fuel type, and mass of dry fuel burned. While particle mass emissions, $\mathrm{EF}_{\mathrm{PM}}$, depend strongly on fuel type, we found no such relation for particle number emissions, $\mathrm{EF}_{\mathrm{PN}}$, which can be explained by differences in particle size alone.

For the emission ratio of particle number to carbon monoxide (PN/CO) we found no dependence on MCE or fuel type. The PM/CO also did not depend on MCE, but was larger for forest fires than for grass and savanna fires.

The above results make possible an efficient description of biomass burning aerosol emissions in dynamic models that provide information about MCE or $\mathrm{CO}$ emissions for vegetation fires, and can thus be linked directly to existing emission inventories. Models describing the climate-driven changes in fuel composition and fire evolution would, together with these dynamic emission factors, give important input to climate-related changes in vegetation fire particle number emission and $\mathrm{CCN}$ effects.

We must point out, however, that the parameterizations presented here are based on a very limited number of measurements and should be tested and confirmed, or refined, by further experimental studies. Well-defined laboratory experiments should help to improve the mechanistic understanding of particle emission/formation and aging, and field data are urgently needed for the validation of the above or similar parameterizations. For proper validation, the experimental studies should comprise measurements of particle number, mass and size distributions as a function of plume age and combustion efficiency.

Acknowledgements. The European Integrated project on Aerosol Cloud Climate and Air Quality interactions (No 036833-2, EUCAARI) and the Max Planck Society (MPG) provided funding for this study. Tracey Andreae is acknowledged for help with editing the manuscript. Thanks to Ken Carslaw, Wei Min Hao, Denier van der Gon, Almut Arneth, Kirsten Thonicke, David Simpson, Guenter Helas, Philipp Reutter, Jörg Trentmann and the EUCAARI community for stimulating discussions.
The service charges for this open access publication have been covered by the Max Planck Society.

Edited by: M. Kulmala

\section{References}

Anderson, B. E., Grant, W. B., Gregory, G. L., Browell, E. V., Collins Jr., J. E., Sachse, G. W., Bagwell, D. R., Hudgins, C. H., and Blake, D. R.: Aerosols from biomass burning over the tropical South Atlantic region: Distributions and impacts, J. Geophys. Res., 101(D19), 24117-24137, 1996.

Andreae, M. O., Anderson, B. E., Blake, D. R., Bradshaw, J. D., Collins, J. E., Gregory, G. L., Sachse, G. W., and Shipham, M. C.: Influence of plumes from biomass burning on atmospheric chemistry over the equatorial and tropical South Atlantic during CITE 3, J. Geophys. Res., 99(D6), 12793-12808, 1994.

Andreae, M. O. and Crutzen, P. J.: Atmospheric Aerosols: Biogeochemical Sources and Role in Atmospheric Chemistry, Science, 276(5315), 1052-1058, 1997.

Andreae, M. O. and Merlet, P.: Emission of trace gases and aerosols from biomass burning, Global Biogeochem. Cycles, 15(4), 955966, 2001.

Andreae, M. O. and Rosenfeld, D.: Aerosol-cloud-precipitation interactions. Part 1. The nature and sources of cloud-active aerosols, Earth Sci. Rev., 89, 13-41, 2008.

Andreae, M. O., Rosenfeldt, D., Artaxo, P., Costa, A. A., Frank, G. P., Longo, K. M., and Silva-Dias, M. A. F.: Smoking rain clouds over the Amazon, Science, 303, 1337-1342, 2004.

Asa-Awuku, A., Sullivan, A. P., Hennigan, C. J., Weber, R. J., and Nenes, A.: Investigation of molar volume and surfactant characteristics of water-soluble organic compounds in biomass burning aerosol, Atmos. Chem. Phys., 8, 799-812, 2008, http://www.atmos-chem-phys.net/8/799/2008/.

Battye, W. and Battye, R.: Development of Emissions Inventory Methods for Wildland Fire. U.S. Environmental Protection Agency Research Triangle Park, North Carolina 27711, EPA Contract No. 68-D-98-046 Work Assignment No. 5-03, 2002.

Browell, E. V., Fenn, M. A., Butler, C. F., Grant, W. B., Clayton, M. B., Fishman, J., Bachmeier, A. S., Anderson, B. E., Gregory, G. L., Fuelberg, H. E., Bradshaw, J. D., Sandholm, S. T., Blake, D. R., Heikes, B. G., Sachse, G. W., Singh, H. B., and Talbot, R. W.: Ozone and aerosol distributions and air mass characteristics over the South Atlantic Basin during the burning season, J. Geophys. Res., 101(D19), 24043-24068, 1996.

Cantrell, C. A.: Technical Note: Review of methods for linear leastsquares fitting of data and application to atmospheric chemistry problems, Atmos. Chem. Phys., 8, 5477-5487, 2008, http://www.atmos-chem-phys.net/8/5477/2008/.

Dhammapala, R., Claiborn, C., Jimenez, J., Corkill, J., Gullett, B., Simpson, C., and Paulsen, M.: Emission factors of PAHs, methoxyphenols, levoglucosan, elemental carbon and organic carbon from simulated wheat and Kentycky bluegrass stubble burns, Atmos. Environ., 41, 2660-2669, 2007.

Eck, T. F., Holben, B. N., Reid, J. S., O’Neill, N. T., Schafer, J. S., Dubovik, O., Smirnov, A., Yamasoe, M. A., and Artaxo, P.: High aerosol optical depth biomass burning events: A comparison of optical properties for different source regions, Geophys. Res. Lett., 30(20), 2035-2038, doi:10.1029/2003GL017861, 2003. 
Falkovich, A. H., Graber, E. R., Schkolnik, G., Rudich, Y., Maenhaut, W., and Artaxo, P.: Low molecular weight organic acids in aerosol particles from Rondônia, Brazil, during the biomassburning, transition and wet periods, Atmos. Chem. Phys., 5, 781797, 2005,

http://www.atmos-chem-phys.net/5/781/2005/.

Feingold, G., Remerm L. A., Ramaprasad, J., and Kaufman, Y. J.: Analysis of smoke impact on clouds in Brazilian biomass burning regions: An extension of Twomey's approach, J. Geophys. Res.-Atmos., 106(D19), 22907-22922, 2001.

Fiebig, M., Stohl, A., Wendisch, M., Eckhardt, S., and Petzold, A.: Dependence of solar radiative forcing of forest fire aerosol on ageing and state of mixture, Atmos. Chem. Phys., 3, 881-891, 2003, http://www.atmos-chem-phys.net/3/881/2003/.

Formenti, P., Boucher, O., Reiner, T., Sprung, D., Andreae, M. O., Wendisch, M., Wex, H., Kindred, D., Tzortziou, M., Vasaras, A., and Zerefos, C.: STAAARTE-MED 1998 summer airborne measurements over the Aegean Sea 2. Aerosol scattering and absorption, and radiative calculations, J. Geophys. Res. 107(D21), 4451, doi:10.1029/2001JD001536, 2002.

Formenti, P., Elbert, W., Maenhaut, W., Haywood, J., Osborne, S., and Andreae, M. O.: Inorganic and carbonaceous aerosols during the Southern African Regional Science Initiative (SAFARI 2000) experiment: Chemical characteristics, physical properties, and emission data for smoke from African biomass burning, J. Geophys. Res., 108(D13), 8488, doi:10.1029/2002JD002408, 2003.

Fuzzi, S., Andreae, M. O., Huebert, B. J., Kulmala, M., Bond, T. C., Boy, M., Doherty, S. J., Guenther, A., Kanakidou, M., Kawamura, K., Kerminen, V.-M., Lohmann, U., Russell, L. M., and Pöschl, U.: Critical assessment of the current state of scientific knowledge, terminology, and research needs concerning the role of organic aerosols in the atmosphere, climate, and global change, Atmos. Chem. Phys., 6, 2017-2038, 2006, http://www.atmos-chem-phys.net/6/2017/2006/.

Fuzzi, S., Descari, S., Facchini, M. C., Cavalli, F., Emblico, L., Mircea, M., Andreae, M. O., Trebs, I., Hoffer, A., Guyon, P., Artaxo, P., Rizzo, L. V., Lara, L. L., Pauliquevis, T., Maenhaut, W., Raes, N., Chi, X., Mauol-Bracero, O. L., Soto-Garcia, L. L., Claeys, M., Kourchev, I., Rissler, J., Swietlicki, E., Tragliavini, E., Schkolnik, G., Falkovich, A. H., Rudich, Y., Fisch, G., and Gatti, L. V.: Overview of the inorganic and organic compostition of size-segregated aerosol in Rondonia, Brazil, from the biomass-burning period to the onset of the wet season, J. Geophys. Res., 112, D01201, doi:10.1029/2005JD006741, 2007.

Gaudichet, A., Echalar, F., Chatenet, B., Quisefit, J. P., Malingre, G., Cachier, H., Buat-Menard, P., Artaxo, P., and Maenhaut, W.: Trace Elements in Tropical African Savanna, Biomass Burning Aerosols, 22, 19-39, 1995.

Guyon, P., Frank, G. P., Welling, M., Chand, D., Artaxo, P., Rizzo, L., Nishioka, G., Kolle, O., Fritsch, H., Silva Dias, M. A. F, Gatti, L. V., Cordova, A. M., and Andreae, M. O.: Airborne measurements of trace gas and aerosol particle emissions from biomass burning in Amazonia, Atmos. Chem. Phys., 5, 2989-3002, 2005, http://www.atmos-chem-phys.net/5/2989/2005/.

Hardy, C. C., Conard, S. G., Regelbrugge, J. C., and Teesdale, D. R.: Smoke Emissions From Prescribed Burning of Southern California Chaparral. U.S. Department of Agriculture, Forest Service, Pacific Northwest Research Station Res. Pap., PNW-RP-
486, 1996.

Hays, M. D., Fine, P. M., Geron, C. D., Kleeman, M. J., and Gullett, B. K.: Open burning of agricultural biomass: Physical and chemical properties of particle-phase emissions, Atmos. Environ., 39, 6747-6764, 2005.

Hays, M. D., Geron, C. D., Linna, K. J., Smith, N. D., and Schauer, J. J.: Speciation of Gas-Phase and Fine Particle Emissions from Burning of Foliar Fuels, Environ. Sci. Technol., 36(11), 22812295, 2002.

Haywood, J. M., Osborne, S. R., Francis, P. N., Keil, A., Formenti, P., Andreae, M. O., and Kaye, P. H.: The mean physical and optical properties of regional haze dominated by biomass burning aerosol measured from the C-130 aircraft during SAFARI 2000, J. Geophys. Res., 108(D13), 8473, doi:10.1029/2002JD002226, 2003.

Hinds, W. C.: Aerosol technology : properties, behavior, and measurement of airborne particles. New York, Wiley-interscience, 1998.

Hobbs, P. V., Reid, J. S., Herring, J. A., Nance, J. D., Weiss, R. E., Ross, J. L., Hegg, D. A., Ottmar, R. D., and Liousse, C.: Particle and trace-gas measurements in smoke from prescribed burns of forest products in the Pacific Northwest, Biomass Burning and Global Change, vol. 1, New York, MIT Press, 1996.

Hobbs, P. V., Sinha, P., Yokelson, R. J., Christian, T. J., Blake, D. R., Gao, S., Kirchstetter, T. W., Novakov, T., and Pilewskie, P.: Evolution of gases and particles from a savanna fire in South Africa, J. Geophys. Res., 108(D13), 8485, doi:10.1029/2002JD002352, 2003.

Hodzic, A., Madronich, S., Bohn, B., Massie, S., Menut, L., and Wiedinmyer, C.: Wildfire particulate matter in Europe during summer 2003: meso-scale modeling of smoke emissions, transport and radiative effects, Atmos. Chem. Phys., 7, 4043-4064, 2007, http://www.atmos-chem-phys.net/7/4043/2007/.

Hu, Y., Odman, M. T., Chang, M. E., Jackson, W., Lee, S., Edgerton, E. S., Baumann, K., and Russell, A. G.: Simulation of Air Quality Impacts from Prescribed Fires on an Urban Area, Environ. Sci. Technol., 42(10), 3676-3682, 2008.

Hungershoefer, K., Zeromskiene, K., Iinuma, Y., Helas, G., Trentmann, J., Trautmann, T., Parmar, R. S., Wiedensohler, A., Andreae, M. O., and Schmid, O.: Modelling the optical properties of fresh biomass burning aerosol produced in a smoke chamber: results from the EFEU campaign, Atmos. Chem. Phys., 8, $3427-$ 3439, 2008,

http://www.atmos-chem-phys.net/8/3427/2008/.

Iinuma, Y., Bruggemann, E., Gnauk, T., Muller, K., Andreae, M. O., Helas, G., Parmar, R., and Herrmann, H.: Source characterization of biomass burning particles: the combustion of selected Eup[eand conifers, African hardwood, savanna grass, and German and Indonesian peat, J. Geophys. Res., 112, D08209, doi:10.1029/2006JD007120, 2007.

Kaufman, Y. J., Setzer, A., Ward, D., Tanre, D., Holben, B. N., Menzel, P., Pereira, M. C., and Rasmussen, R.: Biomass Burning Airborne and Spaceborne Experiment in the Amazonas (Base-a), J. Geophys. Res.-Atmos., 97(D13), 14581-14599, 1992.

Keshtkar, H. and Ashbaugh, L. L.: Size distributions of polycyclic aromatic hydrocarbon particulate emission factors from agricultural burning, Atmos. Environ., 41, 2729-2739, 2007.

Kivekäs, N.: Parameterization of cloud droplet activation using a 
simplified treatment of the aerosol number size distribution, J. Geophys. Res., 113(D15), D15207, doi:10.1029/2007JD009485, 2008.

Korontzi, S., Ward, D. E., Susott, R. A., Yokelson, R. J., Justice, C. O., Hobbs, P. V., Smithwick, E. A. H., and Hao, W. M.: Seasonal variation and ecosystem dependence of emission factors for selected trace gases and PM2.5 for southern African savanna fires, J. Geophys. Res.-Atmos., 108(D24), 4758, doi:10.1029/2003JD003730, 2003.

Kuhn, U., Ganzeveld, L., Thielmann, A., Dindorf, T., Welling, M., Sciare, J., Roberts, G., Meixner, F. X., Kesselmeier, J., Lelieveld, J., Ciccioli, P., Trentmann, J., and Andreae, M. O.: Ozone production, precursor sensitivity and aerosol load, Atmos. Chem. Phys. Discuss., submitted, 2010.

Le Canut, P., Andreae, M. O., Harris, G. W., Wienhold, F. G., and Zenker, T.: Airborne studies of emissions from savanna fires in southern Africa.1. Aerosol emissions measured with a laser optical particle counter, J. Geophys. Res., 101(D19), 23615-23630, 1996.

Lohmann, U., Stier, P., Hoose, C., Ferrachat, S., Kloster, S., Roeckner, E., and Zhang, J.: Cloud microphysics and aerosol indirect effects in the global climate model ECHAM5-HAM, Atmos. Chem. Phys., 7, 3425-3446, 2007,

http://www.atmos-chem-phys.net/7/3425/2007/.

Luderer, G., Trentmann, J., Winterrath, T., Textor, C., Herzog, M., Graf, H. F., and Andreae, M. O.: Modeling of biomass smoke injection into the lower stratosphere by a large forest fire (Part II): sensitivity studies, Atmos. Chem. Phys., 6, 5261-5277, 2006, http://www.atmos-chem-phys.net/6/5261/2006/.

Martins, J. V., Artaxo, P., Hobbs, P. V., Liousse, C., Cachier, H., Kaufman, Y. J., and Plana-Fattori, A.: Particle size distributions, elemental compositions, carbon measurements, and optical properties of smoke from biomass burning in the Pacific Northwest of the United States, Biomass Burning and Global Change, vol. 1, New York, MIT Press, 1996.

Oros, D. R., bin Abas, M. R., Omar, N. Y. M. J., Rahman, N. A., and Simoneit, B. R. T.: Identification and emission factors of molecular tracers in organic aerosols from biomass burning Part 3. Grasses, Appl. Geochem., 21, 919-940, 2006.

Petzold, A., Weinzierl, B., Huntrieser, H., Stohl, A., Real, E., Cozic, J., Fiebig, M., Hendricks, J., Lauer, A., Law, K., Roiger, A., Schlager, H., and Weingartner, E.: Perturbation of the European free troposphere aerosol by North American forest fire plumes during the ICARTT-ITOP experiment in summer 2004, Atmos. Chem. Phys., 7, 5105-5127, 2007,

http://www.atmos-chem-phys.net/7/5105/2007/.

Radke, L. F., Hegg, D. A., Hobbs, P. V., Nance, J. D., Lyons, J. H., Laursen, K. K., Weiss, R. E., Riggan, P. J., and Ward, D. E.: Particulate and trace agas emissions from large biomass fires in North America Global Biomass Burning: Atmospheric, Climatic, and Biospheric Implications, Cambridge, Mass, MIT Press, 1991.

Radke, L. F., Lyons, J. H., Hobbs, P. V., Hegg, D. A., Sandberg, D. V., and Ward, D. E.: Airborne Monitoring and Smoke Characterization of Prescribed Fires on Forest Lands in Western Washington and Oregon: Final Report. USDA Forest Service, 1990.

Reid, J. S., Koppmann, R., Eck, T. F., and Eleuterio, D. P.: A review of biomass burning emissions part II: intensive physical properties of biomass burning particles, Atmos. Chem. Phys., 5, 799-
825, 2005,

http://www.atmos-chem-phys.net/5/799/2005/.

Reid, J. S. and Hobbs, P. V.: Physical and optical properties of young smoke from individual biomass fires in Brazil, J. Geophys. Res., 103(D24), 32013-32030, 1998.

Reid, J. S., Hobbs, P. V., Ferek, R. J., Blake, D. R., Martins, J. V., Dunlap, M. R., and Liousse, C.: Physical, chemical, and optical properties of regional hazes dominated by smoke in Brazil, J. Geophys. Res., 103(D24), 32059-32080, 1998.

Reid, J. S., Eck, T. F., Christopher, S. A., Koppmann, R., Dubovik, O., Eleuterio, D. P., Holben, B. N., Reid, E. A., and Zhang, J.: A review of biomass burning emissions part III: intensive optical properties of biomass burning particles, Atmos. Chem. Phys., 5, 827-849, 2005,

http://www.atmos-chem-phys.net/5/827/2005/.

Reutter, P., Su, H., Trentmann, J., Simmel, M., Rose, D., Gunthe, S. S., Wernli, H., Andreae, M. O., and Pöschl, U.: Aerosol- and updraft-limited regimes of cloud droplet formation: influence of particle number, size and hygroscopicity on the activation of cloud condensation nuclei (CCN), Atmos. Chem. Phys., 9, 70677080, 2009,

http://www.atmos-chem-phys.net/9/7067/2009/.

Rissler, J., Swietlicki, E., Zhou, J., Roberts, G., Andreae, M. O., Gatti, L. V., and Artaxo, P.: Physical properties of the submicrometer aerosol over the Amazon rain forest during the wetto-dry season transition - comparison of modeled and measured CCN concentrations, Atmos. Chem. Phys., 4, 2119-2143, 2004, http://www.atmos-chem-phys.net/4/2119/2004/.

Rissler, J., Vestin, A., Swietlicki, E., Fisch, G., Zhou, J., Artaxo, P., and Andreae, M. O.: Size distribution and hygroscopic properties of aerosol particles from dry-season biomass burning in Amazonia, Atmos. Chem. Phys., 6, 471-491, 2006, http://www.atmos-chem-phys.net/6/471/2006/.

Roberts, G. C., Artaxo, P., Zhou, J. C., Swietlicki, E., and Andreae, M. O.: Sensitivity of CCN spectra on chemical and physical properties of aerosol: A case study from the Amazon Basin, J. Geophys. Res.-Atmos., 107, 8070, doi:10.1029/2001JD000583, 2002.

Rose, D., Nowak, A., Achtert, P., Wiedensohler, A., Hu, M., Shao, M., Zhang, Y., Andreae, M. O., and Pöschl, U.: Cloud condensation nuclei in polluted air and biomass burning smoke near the mega-city Guangzhou, China - Part 1: Size-resolved measurements and implications for the modeling of aerosol particle hygroscopicity and CCN activity, Atmos. Chem. Phys. Discuss., 8, 17343-17392, 2008, http://www.atmos-chem-phys-discuss.net/8/17343/2008/.

Rosenfeld, D., Lohmann, U., Raga, G. B., O’Dowd, C. D., Kulmala, M., Fuzzi, S., Reissell, A., and Andreae, M. O.: Flood or drought: How do aerosols affect precipitation?, Science, 321, 1309-1313, 2008.

Schafer, J. S., Eck, T. F., Holben, B. N., Artaxo, P., and Duarte, A. F.: Characterization of the optical properties of atmospheric aerosols in Amazonia from long-term AERONET monitoring (1993-1995 and 1999-2006), J. Geophys. Res., 113, D04204, doi:10.1029/2007JD009319, 2008.

Scholes, R. J., Ward, D. E., and Justice, C. O.: Emissions of trace gases and aerosol particles due to vegetation burning in southern hemisphere Africa, J. Geophys. Res., 101(D19), 23677-23682, 1996. 
Schultz, M. G., Heil, A., Hoelzemann, J. J., Spessa, A., Thonicke, K., Goldammer, J. G., Held, A. C., Pereira, J. M. C., and van het Bolscher, M.: Global wildland fire emissions from 1960 to 2000, Global Biogeochem. Cycles, 22, GB2002, doi:10.1029/2007GB003031, 2008.

Seinfeld, J. H. and Pandis, S. N.: Atmospheric chemistry and physics: from air pollution to climate change, Hoboken, N. J., Wiley, 2006.

Sinha, P., Hobbs, P. V., Yokelson, R. J., Bertschi, I. T., Blake, D. R., Simpson, I. J., Gao, S., Kirchstetter, T. W., and Novakov, T.: Emissions of trace gases and particle from savanna fires in southern Africa, J. Geophys. Res., 108(D13), 8487, doi:10.1029/2002JD002325, 2003.

Stier, P., Feichter, J., Kinne, S., Kloster, S., Vignati, E., Wilson, J., Ganzeveld, L., Tegen, I., Werner, M., Balkanski, Y., Schulz, M., Boucher, O., Minikin, A., and Petzold, A.: The aerosolclimate model ECHAM5-HAM, Atmos. Chem. Phys., 5, 11251156, 2005, http://www.atmos-chem-phys.net/5/1125/2005/.

Thonicke, K. and Cramer, W.: Long-term trends in vegetation dynamics and forest fires in Brandenburg (Germany) under a changing climate, Nat. Hazards, 38(1-2), 283-300, 2006.

Trentmann, J., Luderer, G., Winterrath, T., Fromm, M. D., Servranckx, R., Textor, C., Herzog, M., Graf, H.-F., and Andreae, M. O.: Modeling of biomass smoke injection into the lower stratosphere by a large forest fire (Part I): reference simulation, Atmos. Chem. Phys., 6, 5247-5260, 2006, http://www.atmos-chem-phys.net/6/5247/2006/.

van der Werf, G. R., Randerson, J. T., Giglio, L., Collatz, G. J., Kasibhatla, P. S., and Arellano Jr., A. F.: Interannual variability in global biomass burning emissions from 1997 to 2004, Atmos. Chem. Phys., 6, 3423-3441, 2006, http://www.atmos-chem-phys.net/6/3423/2006/.

Ward, D. E.: Effect of fuel composition on combustion efficiency and emission factors for African savanna ecosystems, J. Geophys. Res.-Atmos., 101(D19), 23569-23576, 1996.
Ward, D. E. and Hardy, C. C.: Smoke emissions from wildland fires, Environment International, 17, 117-134, 1991.

Ward, D. E., Stezer, A. W., Kaufman, Y. J., and Rasmussen, R. A.: Characteristics of smoke emissions from biomass fires of the Amazon region - BASE-A experiment, Global Biomass Burning: Atmospheric, Climatic, and Biospheric Implications, Cambridge, Mass, MIT Press, 1991.

Ward, D. E., Susott, R. A., Kauffman, J. B., Babbitt, R. E., Cummings, D. L., Dias, B., Holben, B. N., Kaufman, Y. J., Rasmussen, R. A., and Setzer, A. W.: Smoke and fire characteristics for cerrado and deforestaion burns in Brazil BASE-B experiment, J. Geophys. Res., 97, 14601-14619, 1992.

Ward, T. J., Hamilton Jr., R. F., Dixon, R. W., Paulsen, M., and Simpson, C. D.: Characterization and evaluation of smoke tracers in PM: Results from the 2003 Montana wildfire season, Atmos. Environ., 40, 7005-7017, 2006.

Wardoyo, A. Y. P., Morawska, L., Ristovski, Z. D., and Marsh, J.: Quantification of particle number and mass emission factors from combustion of Queensland trees, Environ. Sci. Technol., 40, 5696-5703, 2006.

Yokelson, R. J., Griffith, D. W. T., and Ward, D. E.: Openpath Fourier transform infrared studies of large-scale laboratory biomass fires, J. Geophys. Res., 101(D15), 21067-21080, 1996.

Yokelson, R. J., Karl, T., Artaxo, P., Blake, D. R., Christian, T. J., Griffith, D. W. T., Guenther, A., and Hao, W. M.: The Tropical Forest and Fire Emissions Experiment: overview and airborne fire emission factor measurements, Atmos. Chem. Phys., 7, 5175-5196, 2007, http://www.atmos-chem-phys.net/7/5175/2007/.

Yokelson, R. J., Urbanski, S. P., Atlas, E. L., Toohey, D. W., Alvarado, E. C., Crounse, J. D., Wennberg, P. O., Fisher, M. E., Wold, C. E., Campos, T. L., Adachi, K., Buseck, P. R., and Hao, W. M.: Emissions from forest fires near Mexico City, Atmos. Chem. Phys., 7, 5569-5584, 2007, http://www.atmos-chem-phys.net/7/5569/2007/. 